\title{
Тулиевый волоконный лазер для медицины
}

\author{
А.А. Колегов ${ }^{*}$, Г.С. Софиенко, А.В. Черникова, \\ Е.А. Белов, А.О. Лешков, Ю.В. Ивченко
}

Российский федеральный ядерньій центр - Всероссийский научно-исследовательский институт технической физики имени академика Е.И. Забабахина, Снежинск, Россия

*E-mail: albatrosing@yandex.ru

DOI:10.31868/RFL2018.192-193

C момента создания первых лазеров начались активные исследования воздействия лазерного излучения на биологические ткани и разработка методик лечения разного рода заболеваний с помощью лазерного излучения. В зависимости от мощности лазерного излучения последнее может приводить к нагреву, коагулированию, испарению или разрезанию биоткани. Отсюда можно перечислить ряд преимуществ лазерных медицинских инструментов по сравнению с традиционными:

-высокая температура обеспечивает минимально инвазивный рез благодаря коагуляции;

- высокая температура стерилизует раны и снижает риск заражения;

- минимальный отек ран, уменьшаются послеоперационные последствия;

- сокращается послеоперационный период и сроки лечения.

В настоящее время разработано множество методик лечения заболеваний с помощью лазерного излучения, которые нашли применение в оториноларингологии, дерматокосметологии, лечении сосудистых заболеваний, кардиохирургии, ортопедии и травмоталогии, нейрохирургии, гинекологии и проктологии, хирургии, стоматологии и др.

Характер воздействия излучения на биоткани также зависит от длины волны. Поглощение излучения в биотканях определяет глубину проникновения. Основными веществами, поглощающими излучение в биотканях являются гемоглобин и вода. Так излучение в области 0.94-0.98 мкм гораздо сильнее поглощается в крови чем в воде и обеспечивает оптимальное сочетание режущих и коагулирующих свойств для хирургических целей. Излучение с длиной волны 1.06 мкм часто используется при объемном прогреве тканей.

Излучение в области 1.4-1.8 мкм существенно поглощается в воде. Здесь происходят биофизические процессы, отличные при воздействии излучения с длиной волны 0.94-0.98 мкм. Основную роль при манипуляции излучением с длиной волны 1.4-1.8 мкм играет нагрев воды до $100{ }^{0} \mathrm{C}$ и последующее испарение.

Еще один пик поглощения в биотканях лежит в области 1.8-2.1 мкм, который схож с поглощением излучения $\mathrm{CO} 2$-лазеров. Излучение указанной области спектра обладает хорошими режущими свойствами, малой зоной теплового повреждения и хорошей коагуляцией.

Волоконные лазеры, легированные тулием, могут генерировать излучение с длиной волны от 1900 до 2000 нм, что как раз соответствует пику поглощения в биотканях. Лазеры мощностью до 10 Вт достаточно давно используются в косметологии, ЛОР-хирургии и стоматологии. Лазеры мощностью до 40 Вт успешно используются для остеоперфорации, в геникологии, проктологии и сосудистой патологии. В последнее время стали использоваться лазеры с мощностью 50-120 Вт в урологии для трансуретальной вапоризации простаты. 
В настоящей работе представлены результаты разработки тулиевого волоконного лазера в ФГУП «РФЯЦ-ВНИИТФ им. академ. Е.И. Забабахина» мощностью 40 Вт.

Во многих работах, посвященных тулиевым лазерам, используются волокна с высокой концентрацией ионов тулия, что позволяет максимизировать эффект кроссрелаксации, когда один поглощенный фотон может поднять два иона тулия на верхний лазерный уровень. Таким образом, кроссрелаксация существенно повышает квантовую эффективность тулиевого лазера и использовать накачку с длиной волны в области 790 нм.

Для создания эффективного тулиевого лазера в ФГУП «РФЯЦ ВНИИТФ им. академ. Е.И. Забабахина» было изготовлено активное тулиевое волокно, обеспечивающее эффективность преобразования «свет в свет» около 60\%, что соответствует параметрам мировых производителей.

Лазер выполнен на волокне с диаметром сердцевины 10 мкм и числовой апертурой NA $=0.15$. Диаметр оболочки составляет 125 мкм с числовой апертурой NA $=0.46$. Поглощение по оболочке на длине волны 793 нм составляет 3 дБ/м. Накачка активного волокна выполнена с двух сторон резонатора с помощью объединителей накачки (каплер) типа 2x1 и (6+1)х1. Активное волокно согласовано с сигнальным волокном каплера. В качестве источников накачки используется 4 лазерных модуля накачки с волоконным выходом и максимальной мощностью 30 Вт. Резонатор образован двумя брэгговскими решетками с центральной длиной волны 1940 нм и шириной спектра отражения 0.5 нм.

Лазер состоит из нескольких блоков, объединённых в едином корпусе. Габаритные размеры лазера: 369,5х257×152 мм. Масса лазера 10 кг. Вывод лазерного излучения осуществляется через разъём SMA на задней панели прибора, который может обеспечивать бесстыковое соединение с подключаемым оптоволконным инструментом.

На передней панели лазера расположены: экран, клавиатура и энкодер для ввода параметров, кнопка пуск, кнопка аварийной остановки, ключ включения питания и сигнальный диод включения питания. На задней панели закреплены вентиляторы, гнездо питания, розетка педали включения. Забор воздуха для охлаждения внутреннего объёма осуществляется через прорези в нижней крышке корпуса.

Спектр излучения лазера может быть любым из диапазона 1900-2000 нм благодаря широкому спектру люминесценции активного волокна. Мощность лазера составила 40 Вт. Созданный лазер поддерживает импульснопериодический и непрерывный режим работы. Минимальная длительность импульса и паузы составляет 10 мс.

Таким образом, в ФГУП «РФЯЦ-ВНИИТФ им. академ. Е.И. Забабахина» был создан тулиевый волоконный лазер для медицины, мощностью 40 Вт и длиной волны 1940 нм. В 2018 г. началось проведение предклинических испытаний лазера. В 2019 г. планируется провести клинические испытания лазера и выполнить разработку тулиевого лазера мощностью 120 Вт с дополнительными длинами волн 1560 нм и 976 нм. 